\title{
Ethnic Fractionalisation and Aid Effectiveness
}

\author{
Roland Hodler $a, b, c, *$ and David S. Knight ${ }^{b}$ \\ aDepartment of Economics, University of Lucerne, CH-6002 Lucerne, Switzerland \\ ${ }^{b}$ Department of Economics, University of Melbourne, VIC 3110, Australia \\ 'Study Center Gerzensee, CH-3115 Gerzensee, Switzerland \\ * Corresponding author: Roland Hodler. Telephone: +41 4122957 22. Fax: +41 412295501. \\ E-mail: roland.hodler@unilu.ch
}

\begin{abstract}
We test the hypothesis that the effect of foreign aid on economic growth is positive in ethnically homogenous countries, but decreasing in ethnic fractionalisation. Using panel data covering 114 aid-recipient countries over the period 1962 to 2001, and employing two-stage least squares and GMM estimation techniques, we find a strong support for this hypothesis. Our estimates suggest that foreign aid promotes growth in ethnically homogenous countries, while being ineffective or even harmful in many Sub-Saharan African countries and some ethnically fractionalised countries elsewhere.
\end{abstract}

JEL classification: C23, F35, F43, O11

\section{Introduction}

Economists and political activists from Jeffrey Sachs to Bono have long argued that foreign aid has various positive effects on economic development (Sachs, 2005). Recent contributions scrutinising the voluminous aid-effectiveness literature however find no robust evidence for a positive effect of foreign aid on economic growth (Doucouliagos and Paldam, 2008; Rajan and Subramanian, 2008). In at least some recipient countries,

(C) The author 2011. Published by Oxford University Press on behalf of the Centre for the Study of African Economies. All rights reserved. For permissions, please email: journals.permissions@oup.com 
foreign aid must thus have indirect negative effects on economic growth that offset any positive growth effects.

Svensson (2000) and Hodler (2006) present theoretical models in which rivalling ethnic groups can divert time and resources away from productive to rent-seeking activities. These rent-seeking activities are socially wasteful, but help to channel aid inflows or other public funds towards one's own group. ${ }^{1}$ They may include bribery and corruption, lobbying and political campaigning, distorted policies as well as intimidation or even violence and civil warfare. Focusing on the best equilibrium that can be sustained by trigger strategies in a repeated game, Svensson (2000) shows that an increase in aid inflows induces all groups to engage in more rent seeking to ensure that deviations remain unprofitable. His model thus predicts that there are 'surprisingly small or in fact even contractible effects on welfare and public project provision following increased inflows of foreign aid' (Svensson, 2000, p. 445) in heterogeneous societies. Consistent with his model's predictions, he finds evidence that foreign aid tends to raise corruption in ethnically fractionalised, but not in ethnically homogenous countries. ${ }^{2}$

Hodler (2006) adds the assumption that property rights on produced output are endogenous and their quality decreasing in the share of aggregate resources devoted to rent-seeking activities. Focusing on the one-shot version of the game, he finds that foreign aid has a direct positive effect on economic development and an indirect negative effect as foreign aid increases rent seeking and erodes property rights, thereby making productive activities even less attractive. The magnitude of the direct positive effect is independent of the number of rivalling groups, but the indirect negative effect becomes larger as the the number of rivalling groups increases. The reason is that the increase in aggregate rent seeking that follows higher aid inflows is the larger, the more rivalling groups there are. As a consequence, the model predicts that the net effect of foreign aid on economic development is positive if the number of rivalling

${ }^{1}$ Hodler (2006) focuses on natural resource rents rather than foreign aid. However, windfall gains in the forms of resource rents and (unconditional) aid inflows are likely to have similar effects on a country's economy, its institutions and the political situation, as argued by Acemoglu et al. (2004), Hodler (2006), Dalgaard and Olsson (2008) and many others. For dynamic models of rent seeking and windfall gains, see Lane and Tornell (1996), Tornell and Lane (1999) and Hodler (2007).

${ }^{2}$ Knack (2001), Alesina and Weder (2002), Bräutigam and Knack (2004) and Djankov et al. (2008) provide further evidence that foreign aid can foster corruption and undermine the quality of institutions and governance. 
groups is low, but decreases in the number of rivalling groups and becomes negative if this number gets sufficiently large.

The models of Svensson (2000) and Hodler (2006) predict that the effect of foreign aid on economic development should be clearly positive in ethnically homogenous countries, but smaller or even negative in countries with many rivalling ethnic groups. ${ }^{3}$ In this paper, we test this hypothesis using panel data covering 114 aid recipient countries over the period 1962 to 2001. We are interested in the growth effects of both foreign aid and its interaction with the index of ethnic fractionalisation, which serves as our proxy for the number of rivalling ethnic groups. Employing two-stage least squares and generalised method of moments (GMM) estimation techniques, we find a positive coefficient on foreign aid and a negative coefficient on the interaction term. These findings, which survive various robustness exercises, support our hypothesis. Our estimates suggest that foreign aid is effective in promoting economic growth in relatively ethnically homogenous countries, but that many Sub-Saharan African countries (and a few countries in Latin America and elsewhere) are so ethnically fractionalised that foreign aid is likely to be ineffective or even harmful.

This latter implication is reconcilable with the political reality in various Sub-Saharan African countries. In Kenya, for example, there has long been fierce political competition along ethnic lines, and numerous members of the Kalenjin-dominated government around Daniel arap Moi, who was president from 1978 to 2002, and the Kikuyu-dominated government around Mwai Kibaki, who has been president ever since, have extracted foreign aid and other public funds on a large scale (Wrong, 2009).

Our paper contributes to the aid effectiveness literature, in particular its newer branch, the so-called conditional aid effectiveness literature (Doucouliagos and Paldam, 2010), which studies the conditions under which foreign aid is effective (rather than whether or not foreign aid is effective in an average country). Despite some doubts about the robustness of their findings, Burnside and Dollar (2000) must be credited for initiating the conditional aid effectiveness literature. ${ }^{4}$ Major contributions to this

${ }^{3}$ While Svensson (2000) and Hodler (2006) both focus on rivalling groups divided along ethnic lines in their empirical applications, their theoretical models can also represent situations in which rivalling groups differ in some other characteristics. We however choose to follow Svensson (2000) and Hodler (2006) in focusing on rivalling ethnic groups.

${ }^{4}$ Studies questioning the robustness of the Burnside and Dollar (2000) findings include Hansen and Tarp (2000, 2001), Dalgaard and Hansen (2001), Lensink and White 
literature include Hansen and Tarp (2000, 2001), Dalgaard et al. (2004) and Angeles and Neanidis (2009). ${ }^{5}$ Hansen and Tarp find diminishing returns to foreign aid, i.e., a negative coefficient on aid squared. ${ }^{6}$ Dalgaard and his co-authors find that aid is more effective outside the tropics than within. In particular, they find a positive coefficient on aid, but a negative coefficient on the interaction term between aid and the fraction of a country's area located in the tropics. Angeles and Neanidis hypothesise that aid effectiveness depends on the size of the local elite, which they proxy by the share of colonial settlers. ${ }^{7}$ They indeed find a positive coefficient on aid, but a negative coefficient on the interaction term between aid and the share of colonial settlers.

We compare our results to these findings. We find that the interaction term between aid and ethnic fractionalisation tends to be more robust than an aid-squared term and the interaction term between aid and the fraction of a country's area located in the tropics. We also find evidence that ethnic fractionalisation and the share of colonial settlers both lower aid effectiveness. Inspired by Caselli and Coleman (2006), we argue that this latter finding may suggest that rent-seeking contests for aid inflows do not only get more detrimental as the number of ethnic groups raises, but also as the differences in physical appearance across the major ethnic groups grow larger.

Our paper also relates to the literature on the consequences of ethnic diversity for economic development. Easterly and Levine (1997) find that ethnic fractionalisation may be responsible for Sub-Saharan Africa's poor growth performance by causing rent seeking, poor policies and weak institutions. ${ }^{8}$ We also find that ethnic fractionalisation has a significantly

(2001), Easterly et al. (2004), Roodman (2004, 2007), Jensen and Paldam (2006) and Doucouliagos and Paldam (2010).

${ }^{5}$ Doucouliagos and Paldam (2010) and Roodman (2004, 2007) discuss various contributions to the conditional aid effectiveness literature. Roodman's robustness exercises suggest that the findings of Hansen and Tarp (2001) and Dalgaard et al. (2004) tend to be more robust than other findings in this literature. These robustness exercises do however not include the most recent contributions, e.g., Angeles and Neanidis (2009) and also not all of the earlier contributions, e.g., Ovaska (2003).

${ }^{6}$ See also Dalgaard and Hansen (2001) and Lensink and White (2001).

7 Bjørnskov (2009) studies in what circumstances foreign aid benefits the local elite.

${ }^{8}$ La Porta et al. (1999) and Alesina et al. (2003) also find that ethnic fractionalisation leads to poor policy outcomes and bad governance; and Miguel and Guerty (2005) illustrate the negative effect of ethnic divisions on the provision of local public goods in rural Kenya. 
negative effect on economic growth in specifications in which we exclude the interaction term of foreign aid and ethnic fractionalisation. But whenever we include this interaction term, ethnic fractionalisation by itself becomes insignificant. Hence, our results suggest that ethnic heterogeneity is not in and of itself detrimental to economic growth, but lowers the effectiveness of foreign aid.

The remainder of this paper is structured as follows: Section 2 discusses our empirical methodology and the data. Section 3 presents our main results and various robustness exercises. Section 4 concludes.

\section{Methodology and data}

We employ panel data covering 114 aid-recipient countries over the period 1962 to $2001 .{ }^{9}$ We use four-year averages of our measures of foreign aid and economic growth. To test whether the aid-growth relationship varies systematically with ethnic fractionalisation, we estimate the following model:

$$
\begin{aligned}
\mathrm{GROWTH}_{i t}= & \alpha+\beta_{1} \mathrm{AID}_{i t}+\beta_{2} \mathrm{ETHNIC}_{i}+\beta_{3}\left(\mathrm{AID}_{i t} \times \mathrm{ETHNIC}_{i}\right) \\
& +X_{i t}^{\prime} \Lambda+\varepsilon_{i t},
\end{aligned}
$$

where GROWTH ${ }_{i t}$ is the average growth rate of real per capita GDP in country $i$ from year $t$ to year $t+3, \operatorname{AID}_{i t}$ a measure of average yearly aid inflows in this period, ETHNIC $i$ an index of ethnic fractionalisation and $X_{i t}$ a vector of other control variables.

We are mainly interested in the effect of a change in $\mathrm{AID}_{i t}$ on GROWTH $_{i t}$. The point estimate of this effect is $\beta_{1}+\beta_{2}$ ETHNIC $_{i}$. Our hypothesis suggests that $\beta_{1}$ should be significantly positive and $\beta_{2}$ should be significantly negative. The point estimates would then imply that $\mathrm{GROWTH}_{i t}$ is increasing in $\mathrm{AID}_{i t}$ if $\mathrm{ETHNIC}_{i}$ is below the threshold of $-\beta_{1} / \beta_{2}$, but decreasing in $\operatorname{AID}_{i t}$ otherwise.

We use the measures of GROWTH ${ }_{i t}$ and AID $_{i t}$ from the extensive data set compiled by Roodman (2004). ${ }^{10}$ This data set contains three measures of aid inflows: Effective development assistance (EDA) relative to real GDP, net overseas development assistance (ODA) relative to real GDP and ODA relative to exchange rate GDP, i.e., GDP converted to US dollars using market exchange rates rather than purchasing power parities (PPP). The

9 Due to data limitations, the panel is unbalanced and not all specifications cover exactly 114 countries.

${ }^{10}$ Appendix A provides definitions and sources of all variables used. 
Table 1: Summary Statistics

\begin{tabular}{llllll}
\hline Variable & $\begin{array}{l}\text { Number of } \\
\text { observations }\end{array}$ & Mean & $\begin{array}{l}\text { Standard } \\
\text { deviation }\end{array}$ & Minimum & Maximum \\
\hline GROWTH $_{i t}$ & 763 & 0.013 & 0.042 & -0.425 & 0.165 \\
AID $_{i t}$ & 763 & 0.014 & 0.024 & -0.005 & 0.237 \\
ETHNIC $_{i}$ & 114 & 0.492 & 0.261 & 0.000 & 0.930 \\
\hline
\end{tabular}

EDA data correct for a number of short-comings in the ODA data and should therefore be conceptually superior in measuring the true aid element of grants and loans (Chang et al., 1998). We follow the recent literature by using EDA-to-real GDP $\left(\mathrm{AID}_{i t}\right)$ in our baseline specifications, and ODA-to-real GDP $\left(\mathrm{ODA}_{i t}^{R}\right)$ as well as ODA-to-exchange rate GDP $\left(\mathrm{ODA}_{i t}^{X}\right)$ to check the robustness of our results.

We use the index of ethnic fractionalisation $\left(\mathrm{ETHNIC}_{i}\right)$ by Alesina et al. (2003) to proxy for the number of rivalling ethnic groups. This index measures the probability that two randomly selected individuals of a particular country belong to different ethno-linguistic groups. Hence, higher scores indicate a more fractionalised country. This index is only available as a cross section, but we are not concerned by this because the ethnic composition of countries tends to be very slow moving (Alesina et al., 2003). We also use the similarly constructed indices of linguistic and religious fractionalisation (LANGUAGE $i$ and RELIGION $_{i}$ ). Table 1 provides summary statistics for our three main variables - $\mathrm{GROWTH}_{i t}, \mathrm{AID}_{i t}$ and ETHNIC $_{i}$ - based on all observations used in our baseline specifications.

Following the literature, our control variables include 'initial' real PPP-adjusted GDP per capita in year $t\left(\mathrm{GDP}_{i t}\right)$, and a dummy variable for the fast-growing East Asian countries. ${ }^{11}$ Over the period 1962 to 2001, the average growth rate in these countries was close with $5 \%$ compared with $1 \%$ in the rest of the sample.

Many studies in the aid effectiveness literature further add control variables that proxy for fiscal, monetary and trade policies, institutional quality, political stability and governance. We refrain from adding such control variables. The models of Svensson (2000) and Hodler (2006) suggest that the rent-seeking activities caused by aid inflows into ethnically diverse countries go hand-in-hand with poor policies and may lead to a

11 This dummy, which is also taken from Roodman (2004), is equal to one for China, Indonesia, South Korea, Malaysia, Philippines, Singapore and Thailand. 
deterioration in institutional quality. The resulting rent-seeking contestsare also likely to be associated with political instability and bad governance. These models therefore predict that, in fractionalised countries, foreign aid has an indirect negative effect on economic growth, which may well work via rent seeking, poor policies, bad governance, political instability and weak institutions. We can therefore only test our hypothesis whether we exclude these variables. Otherwise, we would be testing whether ethnic fractionalisation impacts upon the aid-growth relationship through some channel unrelated to policies, governance, political stability and institutional quality.

For similar reasons, we follow the literature in not controlling for investment in our main specification. Investment is a very proximate cause of economic growth (e.g., Rodrik, 2003). When controlling for investment, one would test whether ethnic fractionalisation impacts upon the aidgrowth relationship through some channel that leaves investment unaffected. However, we would like to test whether ethnic fractionalisation impacts upon the aid-growth relationship in general, i.e., including through all the channels that affect investment. We can only test this latter hypothesis when we exclude investment from our main specification. We however return to the role of investment below.

To reduce the possibility of omitted variables biasing the relationship between aid and growth, we add year dummies to account for time varying common shocks, and regional dummies to control for regional fixed effects (both of which are omitted in most other contributions to the aid effectiveness literature). ${ }^{12}$ The instrumental variables approach that we adopt will also help to identify the causal relationship between aid and growth.

As a positive side-effect of excluding policy, governance and institutional variables, our sample contains a larger cross section of countries than previous studies. Our baseline specifications are based on 763 observations from 114 countries, while the baseline specification is based on, for example, 275 observations from 56 countries in Burnside and Dollar (2000), and 449 observations from 67 countries in Angeles and Neanidis (2009). As policy, governance and institutional variables tend to be missing more often for countries with poor policies, bad governance,

12 The regions are East Asia and the Pacific, Eastern Europe and Central Asia, Latin America and the Caribbean, the Middle East and North Africa, South Asia and Sub-Saharan Africa. Given that we follow the literature by including a dummy for the fast-growing East Asian countries (see above), we are in fact dividing East Asia and the Pacific into two groups: the fast-growing East Asian countries and the rest. 
weak institutions and low growth rates, we expect our results to be less prone to sample selection bias than those of previous studies.

The potential endogeneity of foreign aid has been the main challenge in the empirical aid effectiveness literature. We follow the literature in choosing estimation techniques that help to address this potential endogeneity. The first technique that we use is two-stage least squares (2SLS). Following the literature (e.g., Boone, 1996; Burnside and Dollar, 2000; Hansen and Tarp, 2001; Dalgaard et al., 2004; Angeles and Neanidis, 2009), we use as instruments for $\operatorname{AID}_{i t}$ a dummy for the Franc zone $\left(\mathrm{FRZ}_{i}\right)$, a dummy for Central American countries $\left(\mathrm{CAM}_{i}\right)$, a dummy for Egypt $\left(\mathrm{EGY}_{i}\right)$, arms imports divided by GDP $\left(\mathrm{ARMS}_{i t}\right)$ and log population size $\left(\mathrm{POP}_{i t}\right)$. These instruments are inspired by various studies, showing that strategic and cultural ties are important determinants of aid flows. Countries in the Franc zone and Central America receive more aid from France and the USA, respectively, for cultural reasons unrelated to economic performance, while Egypt receives more aid for geopolitical reasons. Donors also tend to give more aid per capita to small countries as well as to countries that have arms deals with them, again for reasons unrelated to economic performance. We deviate from most of the literature by not using lagged aid as an instrument in our 2SLS estimates, as average growth in, say, the period from 1998 to 2001 may well depend on aid inflows in, say, 1997, which would violate the instrument exogeneity requirement. To ensure that our set of instruments is sufficiently strong despite dropping lagged aid, we add quadratics of $\mathrm{ARMS}_{i t}$ and $\mathrm{POP}_{i t}{ }^{13}$ Since, we need to instrument for $\mathrm{AID}_{i t}$ as well as its interaction with ETHNIC $_{i}$, we also add $\mathrm{ARMS}_{i t} \times \mathrm{ETHNIC}_{i}$ and $\mathrm{POP}_{i t} \times \mathrm{ETHNIC}_{i}$ to our set of instruments. ${ }^{14}$

We further address the potential endogeneity of foreign aid also by using the generalised method of moments GMM panel estimators of Arellano and Bond (1991) and Blundell and Bond (1998). These estimators have become increasingly popular in the aid effectiveness literature (e.g., Hansen and Tarp, 2001; Dalgaard et al., 2004; Roodman, 2004; Rajan and Subramanian, 2008; Angeles and Neanidis, 2009). They make use of standard instruments, such as those discussed above, but expand the instrument set to improve the efficiency of the first-stage regression. The

${ }^{13}$ Dividing arms imports by GDP rather than total imports also helps to avoid weak instrument problems.

${ }^{14}$ Further adding $\mathrm{ARMS}_{i t}^{2} \times \mathrm{ETHNIC}_{i}$ and $\mathrm{POP}_{i t}^{2} \times \mathrm{ETHNIC}_{i}$ to our set of instruments does not lead to any noticeable change in our results. 
Arellano-Bond estimator converts endogenous variables into first differences and uses lagged levels of the endogenous variables to instrument for these differences, which is why it is commonly referred to as the difference-GMM estimator. The Blundell-Bond estimator adds the levels of the endogenous variables to the system to be instrumented and uses the lagged first differences as additional instruments. This is known as the system-GMM estimator. ${ }^{15}$ We apply these GMM estimators using a two-step estimation process, which tends to be more efficient than a one-step process, and the Windmeijer (2005) finite-sample correction to adjust the standard errors. To avoid dynamic panel bias, we treat $\mathrm{AID}_{i t}$ and $\mathrm{AID}_{i t} \times \mathrm{ETHNIC}_{i}$ as well as $\mathrm{GDP}_{i t}$ as endogenous variables. ${ }^{16}$

Besides addressing the potential endogeneity of aid, these GMM estimators have the added advantage that they incorporate (implicitly) fixed effects' (Rajan and Subramanian, 2008, p. 644). The possibility to control for unobserved country-specific heterogeneity is particularly valuable in our study, in which we cannot control for policy and governance variables because of the hypothesized channels through which ethnic fractionalisation impacts upon aid effectiveness.

When employing these GMM panel estimators, we use only endogenous variables that are lagged at least twice as instruments. When the number of lags of the endogenous variables used as instruments is otherwise unrestricted, GMM panel estimators may create numerous instruments that 'can overfit the instrumented variables' (Roodman, 2004, p. 25). Therefore, we mostly use only the second and third lags of the endogenous variables as instruments, but we also report the results when using all endogenous variables lagged at least twice, and when collapsing the set of instruments using the method proposed by Roodman (2009).

\section{Findings}

Table 2 presents our main results using pooled OLS and, more importantly, 2SLS. In Columns 1 and 2 we look at the effects of $\mathrm{AID}_{i t}$ and $\mathrm{ETHNIC}_{i}$ on GROWTH $_{i t}$ in the absence of the interaction term AID $_{i t} \times$ ETHNIC $_{i}$. We find that the effect of $\mathrm{AID}_{i t}$ is not significantly different from zero, while ETHNIC $_{i}$ has a significant negative effect. The former result suggests

15 These estimators both have their limitations. The difference-GMM estimator often leads to a weak instruments problem, while the system-GMM is only valid if the lagged differences are orthogonal to the fixed effects.

16 This implies that we use lagged aid as instrument for current aid in our GMM estimates. 
Table 2: Main results (OLS and 2SLS)

\begin{tabular}{|c|c|c|c|c|c|c|c|}
\hline \multirow[t]{3}{*}{ Dependent variable } & (1) & (2) & (3) & (4) & (5) & (6) & (7) \\
\hline & OLS & 2SLS & OLS & 2SLS & $2 S L S$ & 2SLS & 2SLS \\
\hline & GROWTH $_{i t}$ & GROWTH $_{i t}$ & GROWTH $_{i t}$ & GROWTH $_{i t}$ & GROWTH $_{i t}$ & GROWTH $_{i t}$ & $\mathrm{INV}_{i t}$ \\
\hline \multirow[t]{2}{*}{$\operatorname{AID}_{i t}$} & -0.170 & 0.223 & 0.507 & 1.399 & 1.249 & 2.000 & 6.125 \\
\hline & $(0.465)$ & $(0.202)$ & $(0.176)$ & $(0.034)$ & $(0.044)$ & $(0.028)$ & $(0.030)$ \\
\hline \multirow[t]{2}{*}{ ETHNIC $_{i}$} & -0.031 & -0.031 & -0.016 & -0.005 & -0.007 & 0.004 & 0.035 \\
\hline & $(0.000)$ & $(0.000)$ & $(0.158)$ & $(0.750)$ & $(0.635)$ & $(0.841)$ & $(0.588)$ \\
\hline \multirow[t]{2}{*}{$\operatorname{AID}_{i t}{ }^{*} \mathrm{ETHNIC}_{i}$} & & & -1.066 & -1.874 & -1.822 & -2.636 & -6.771 \\
\hline & & & $(0.139)$ & $(0.053)$ & $(0.058)$ & $(0.051)$ & $(0.081)$ \\
\hline \multirow[t]{2}{*}{$G D P_{i t}$} & -0.001 & 0.004 & -0.002 & 0.003 & -0.001 & 0.002 & 0.047 \\
\hline & $(0.836)$ & $(0.369)$ & $(0.750)$ & $(0.554)$ & $(0.896)$ & $(0.632)$ & (0.004) \\
\hline Year dummies & YES & YES & YES & YES & YES & YES & YES \\
\hline Regional dummies & YES & YES & YES & YES & YES & YES & YES \\
\hline Implied threshold $-\beta_{1} / \beta_{3}$ & & & $(0.48)$ & 0.75 & 0.69 & 0.76 & 0.90 \\
\hline Countries & 114 & 114 & 114 & 114 & 114 & 92 & 114 \\
\hline Observations & 763 & 763 & 763 & 763 & 752 & 626 & 763 \\
\hline$R^{2}$ & 0.158 & 0.200 & 0.176 & 0.209 & 0.239 & 0.188 & 0.199 \\
\hline Hansen $J$-test ( $p$-value) & - & 0.244 & - & 0.342 & 0.484 & 0.321 & 0.798 \\
\hline Omitted observations & & & & & Statistical outliers & $\begin{array}{l}\text { Countries with low } \\
\text { or high ETHNIC }\end{array}$ & \\
\hline
\end{tabular}

Notes: $p$-values in parentheses are based on robust and clustered standard errors. In all 2SLS regressions, exogenous variables used as instruments include $\mathrm{FRZ}_{i}, \mathrm{CAM}_{i}, \mathrm{EGY}_{i}$, $\mathrm{POP}_{i t}, \mathrm{POP}_{i t}^{2}, \mathrm{ARMS}_{i t}$ and $\mathrm{ARMS}_{i t}^{2}$. In addition, $\mathrm{POP}_{i t}{ }^{*} \mathrm{ETHNIC}_{i}$ and $\mathrm{ARMS}_{i t}{ }^{*} \mathrm{ETHNIC}_{i}$ are used in Columns 4-7. In Column 5, outliers are removed using the Hadi (1992) procedure (see footnote 21 for details). The outliers are GAB 1974-1977; GNB 1974-1977, 1982-1985, 1986-1989; IRQ 1990-1993; JOR 1974-1977, 1978-1981, 1982-1985; LBR 1990-1993, $1998-2001$ and SOM 1974-1977. In Column 6, countries with ETHNIC $C_{i}$ below the 10th or above the 90th percentile are omitted. 
that foreign aid has no effect in an average aid-recipient country, which is consistent with the findings of various recent contributions to the aid effectiveness literature (Doucouliagos and Paldam, 2008; Rajan and Subramanian, 2008); and the latter result is consistent with the findings of Easterly and Levine (1997), who argue that ethnic divisions may be responsible for Sub-Saharan Africa's poor growth performance. In addition, the effect of $\mathrm{GDP}_{i t}$ is also insignificant. ${ }^{17}$

In Column 3, we use pooled OLS to estimate our baseline specification, which includes the interaction term AID $_{i t} \times$ ETHNIC $_{i}$. The coefficients on $\mathrm{AID}_{i t}$ and the interaction term have the predicted signs, but are statistically insignificant. In Column 4, we address the potential endogeneity of $\operatorname{AID}_{i t}$ and $\mathrm{AID}_{i t} \times \mathrm{ETHNIC}_{i}$ using $2 \mathrm{SLS}$ with the set of instruments discussed in the previous section. The Hansen $J$-test is often used to assess the validity of the instruments. We cannot reject the null hypothesis that the excluded instruments are uncorrelated with the error term and, therefore, exogenous. ${ }^{18}$ We find that the coefficient on $\mathrm{AID}_{i t}$ is positive and statistically significant (with a $p$-value of 0.034 ), while the coefficient on $\operatorname{AID}_{i t} \times$ ETHNIC $_{i}$ is negative and statistically significant (with a $p$-value of 0.053). These results support our hypothesis. In particular, the former result suggests that the effect of $\mathrm{AID}_{i t}$ on $\mathrm{GROWTH}_{i}$ is unambiguously positive in ethnically homogenous countries (where $\mathrm{ETHNIC}_{i}=0$ ), while the later result suggests that the effect of $\mathrm{AID}_{i t}$ on $\mathrm{GROWTH}_{i t}$ decreases in $\mathrm{ETHNIC}_{i}$. In Figure 1, following Brambor et al. (2006), we present the effect of $\mathrm{AID}_{i t}$ on $\mathrm{GROWTH}_{i t}$ as well as the associated standard errors for all possible levels of ETHNIC $i$. The effect of $\mathrm{AID}_{i t}$ on $\mathrm{GROWTH}_{i t}$ is significantly positive for low levels of $\mathrm{ETHNIC}_{i}$, but becomes insignificant for high levels of ETHNIC $i$. The point estimates suggest that this effect turns negative once ETHNIC $i$ exceeds the threshold level of 0.75 . This is the case in 21 of the 114 countries in our baseline sample, including 20 of the 43 Sub-Saharan African countries. In these countries, the positive

${ }^{17}$ In all OLS and 2SLS estimates presented in the paper, the coefficients on the dummies for the first four 4-year periods tend to be higher than the dummies for the six later 4-year periods. Moreover, when omitting the dummy for Sub-Saharan African countries, then the dummy for the fast-growing East Asian countries is positive and highly significant, and the South Asia dummy is also positive and significant in most specifications, while all other regional dummies are insignificant.

18 Also the Anderson canonical correlations LR test is sometimes used to assess the relevance of the instruments. In all 2SLS estimates presented in this paper, the null hypothesis can be easily rejected, which suggests that the models are identified and the instruments relevant. 


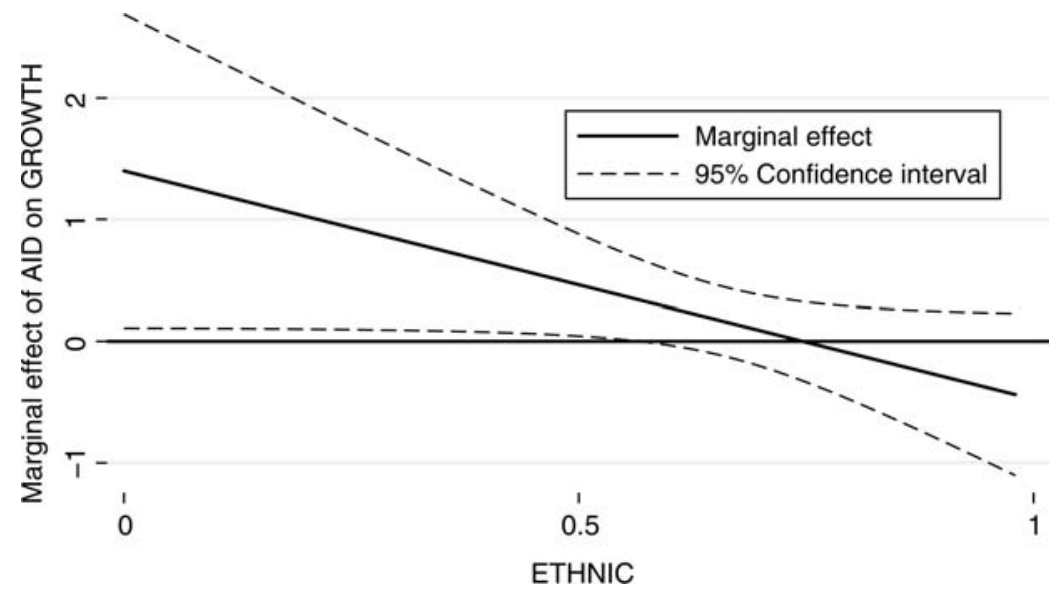

Figure 1: Aid Effectiveness and Ethnic Fractionalisation (2SLS Estimates)

effects of foreign aid are presumably offset by the negative consequences of the provoked rent-seeking contests among rivalling ethnic groups.

To get an idea how sizeable the effect of ethnic fractionalisation on aid effectiveness is, let us first consider the case of Uganda. Uganda is the most ethnically fractionalised country in the world with ETHNIC $_{\mathrm{UGA}}=$ 0.930 . Over the period 1998 to 2001, it received EDA equal to only 1.2\% of its GDP, and its average yearly growth rate was $2.5 \%$. Our point estimates suggest that the contribution of these aid inflows to its growth rate was $-0.4 \%$, i.e., that Uganda would have grown at a rate of $2.9 \%$ in the absence of foreign aid. However, the contribution of these aid inflows to its growth rate would have been $0.6 \%$ if Uganda were about as ethnically fractionalised as the average country in our sample (such as Nicaragua or Venezuela), and even $1.7 \%$ if Uganda were perfectly ethnically homogenous (such as Comoros). ${ }^{19}$

Sierra Leone is another highly fractionalised country with ETHNIC $_{\text {SLE }}=0.820$. In the 1980 s, Sierra Leone was a country strongly influenced by tribal and power politics, where corruption and rent seeking were allegedly rife (Reno, 1995). In the period 1986 to 1989, EDA inflows averaged $1.5 \%$ of GDP. Over this period, real GDP on average declined by $1.6 \%$ a year. According to our estimates, these aid inflows may have contributed to declining GDP by adding to the incentives to engage in rent-seeking activities, with aid inflows estimated to have

19 These contributions are calculated as follows: $(1.399-1.874 \times 0.930) 0.012=-0.004$, $(1.399-1.874 \times 0.492) 0.012=0.006$, and $1.399 \times 0.012=0.017$. 
contributed $-0.2 \%$ a year to growth. In comparison, if Sierra Leone had been as ethnically fractionalised as the average country, aid would have raised the growth by $0.7 \%$ a year, and even by $2.1 \%$ with perfect ethnic homogeneity. ${ }^{20}$ These counterfactuals highlight that the effect of ethnic fractionalisation on aid effectiveness is not only statistically, but also economically significant.

While we are mainly interested in the effects of $\mathrm{AID}_{i t}$ and $\mathrm{AID}_{i t} \times$ ETHNIC $_{i}$ on $\mathrm{GROWTH}_{i}$, it is also noteworthy that ETHNIC $i$ becomes insignificant whenever the interaction term $\mathrm{AID}_{i t} \times \mathrm{ETHNIC}_{i}$ is included. This result suggests that ethnic heterogeneity in and of itself does not have a negative effect on economic growth, but acts to lower the effectiveness of foreign aid.

In Column 5, we account for the possibility that outliers may drive our results by using the Hadi (1992) procedure to identify and remove outliers. In the absence of outliers, the coefficients of interest are of similar magnitude and statistical significance as and when the full sample is used. ${ }^{21}$ In Column 6, we omit the $10 \%$ least and the $10 \%$ most ethnically fractionalised countries from our sample. We again find that the coefficients of interest remain significant, and they become even somewhat larger in magnitude.

As investment is generally seen as a very proximate determinant of economic growth, we expect $\mathrm{AID}_{i t}$ and $\mathrm{AID}_{i t} \times \mathrm{ETHNIC}_{i}$ to have qualitatively similar effects on investment $\left(\mathrm{INV}_{i t}\right)$ as they have on economic growth. This is confirmed by the results in Column 7, where the dependent variable is $\mathrm{INV}_{i t}$ rather than $\mathrm{GROWTH}_{i t}$.

Table 3 presents our main results using GMM estimation techniques to address the potential endogeneity of foreign aid as well as to account for country-specific unobserved heterogeneity. In Columns 1 and 2, we employ the system-GMM estimator using only the second and third lags of the endogenous variables as instruments. The Hansen J-test suggests in both cases that the exogeneity of the instruments cannot be rejected;

${ }^{20}$ These contributions are calculated as follows: $(1.399-1.874 \times 0.820) 0.015=-0.002$, $(1.399-1.874 \times 0.492) 0.015=0.007$ and $1.399 \times 0.015=0.021$.

${ }^{21}$ The Hadi (1992) procedure is used by, e.g., Roodman (2004) and Angeles and Neanidis (2009). We use a 5\% significance level to remove outliers to the partial scatter plot of GROWTH $_{i t}$ against the predicted values of $\mathrm{AID}_{i t} \times \mathrm{ETHNIC}_{i}$ after projection onto the instruments. The countries with most outliers are Guinea-Bissau and Jordan (as noted in Table 2). Our results also survive if we only exclude any or both of these two countries, or if we use other standard tests for outliers based on Cook's Distance, DFITS and the standardized residuals. 
Table 3: Main Results (GMM)

\begin{tabular}{|c|c|c|c|c|c|c|c|}
\hline Dependent variable & $\begin{array}{l}\text { (1) } \\
\text { GMM (SYS) } \\
\text { GROWTH }_{i t}\end{array}$ & $\begin{array}{l}(2) \\
\text { GMM (SYS) }^{\text {GROWTH }}{ }_{i t}\end{array}$ & $\begin{array}{l}\text { (3) } \\
\text { GMM (SYS) } \\
\text { GROWTH }_{i t}\end{array}$ & $\begin{array}{l}\text { (4) } \\
\text { GMM (SYS) } \\
\text { GROWTH }_{i t}\end{array}$ & $\begin{array}{l}(5) \\
\text { GMM (SYS) }^{\text {GROWTH }}{ }_{i t}\end{array}$ & $\begin{array}{l}\text { (6) } \\
\text { GMM (DIFF) } \text { GROWTH }_{i t}\end{array}$ & $\begin{array}{l}\text { (7) } \\
\text { GMM (SYS) } \\
\text { INV }_{i t}\end{array}$ \\
\hline $\operatorname{AID}_{i t}$ & $\begin{array}{c}-0.036 \\
(0.765)\end{array}$ & $\begin{array}{c}0.776 \\
(0.005)\end{array}$ & $\begin{array}{c}0.697 \\
(0.036)\end{array}$ & $\begin{array}{c}0.718 \\
(0.009)\end{array}$ & $\begin{array}{c}1.395 \\
(0.000)\end{array}$ & $\begin{array}{c}1.658 \\
(0.105)\end{array}$ & $\begin{array}{l}2.111 \\
(0.004)\end{array}$ \\
\hline $\mathrm{AID}_{i t}{ }^{*} \mathrm{ETHNIC}_{i}$ & & $\begin{array}{r}-1.577 \\
(0.001)\end{array}$ & $\begin{array}{r}-1.220 \\
(0.009)\end{array}$ & $\begin{array}{r}-1.407 \\
(0.005)\end{array}$ & $\begin{array}{c}-2.212 \\
(0.002)\end{array}$ & $\begin{array}{c}-3.111 \\
(0.072)\end{array}$ & $\begin{array}{r}-3.730 \\
(0.011)\end{array}$ \\
\hline $\mathrm{GDP}_{i t}$ & $\begin{array}{c}0.002 \\
(0.637)\end{array}$ & $\begin{array}{c}-0.002 \\
(0.524)\end{array}$ & $\begin{array}{c}-0.003 \\
(0.371)\end{array}$ & $\begin{array}{c}-0.002 \\
(0.603)\end{array}$ & $\begin{array}{c}0.001 \\
(0.915)\end{array}$ & $\begin{array}{c}-0.020 \\
(0.111)\end{array}$ & $\begin{array}{c}0.053 \\
(0.000)\end{array}$ \\
\hline Year dummies & YES & YES & YES & YES & YES & YES & YES \\
\hline Regional dummies & NO & NO & NO & NO & NO & NO & NO \\
\hline Implied threshold $-\beta_{1} / \beta_{2}$ & & 0.49 & 0.57 & 0.51 & 0.63 & $(0.53)$ & 0.57 \\
\hline Countries & 114 & 114 & 92 & 114 & 114 & 107 & 114 \\
\hline Observations & 763 & 763 & 626 & 763 & 763 & 649 & 763 \\
\hline Hansen $J$-test ( $p$-value) & 0.245 & 0.470 & 0.572 & 0.495 & 0.117 & 0.333 & 0.488 \\
\hline AR(2) test ( $p$-value) & 0.930 & 0.833 & 0.975 & 0.855 & 0.753 & 0.517 & 0.021 \\
\hline GMM instrument count & 36 & 56 & 56 & 76 & 34 & 58 & 56 \\
\hline $\begin{array}{l}\text { Lags of endogenous } \\
\text { variables used } \\
\text { as instruments } \\
\text { Omitted observations }\end{array}$ & $\begin{array}{l}\text { Two and } \\
\text { three lags }\end{array}$ & $\begin{array}{l}\text { Two and } \\
\text { three lags }\end{array}$ & $\begin{array}{l}\text { Two and } \\
\text { three lags } \\
\text { Countries } \\
\text { with low or } \\
\text { high ETHNIC } i\end{array}$ & $\begin{array}{l}\text { Unrestricted } \\
\text { starting with } \\
\text { two lags }\end{array}$ & $\begin{array}{l}\text { Unrestricted starting } \\
\text { with two lags } \\
\text { and collapsed set }\end{array}$ & $\begin{array}{l}\text { Unrestricted } \\
\text { starting with } \\
\text { two lags }\end{array}$ & $\begin{array}{l}\text { Two and } \\
\text { three lags }\end{array}$ \\
\hline
\end{tabular}

Notes: $p$-values in parentheses are based on robust standard errors and the Windmeijer (2005) finite-sample correction. In all columns, exogenous variables used as instruments include $\mathrm{FRZ}_{i}, \mathrm{CAM}_{i}, \mathrm{EGY}_{i}, \mathrm{POP}_{i t}, \mathrm{POP}_{i t}^{2}, \mathrm{ARMS}_{i t}$ and $\mathrm{ARMS}_{i t}^{2}$. In addition, $\mathrm{POP}_{i t}{ }^{*} \mathrm{ETHNIC}_{i}$ and ARMS $_{i t}{ }^{*}$ ETHNIC $_{i}$ are used in Columns 2-7. In Column 3, countries with ETHNIC $C_{i}$ below the 10th or above the 90th percentile are omitted. 


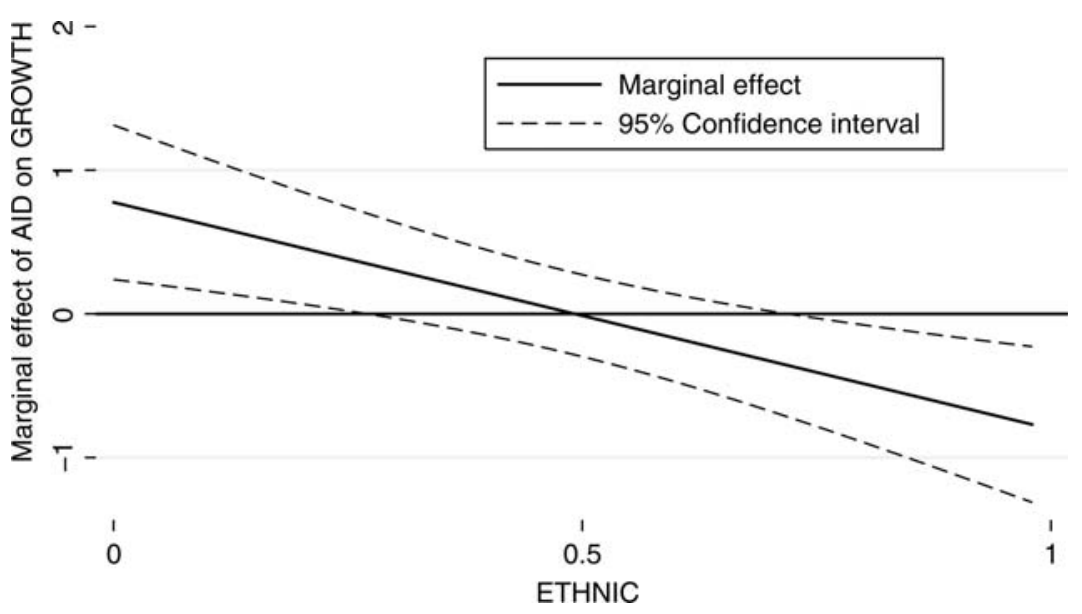

Figure 2: Aid Effectiveness and Ethnic Fractionalisation (GMM Estimates)

and the Arellano-Bond test for $\mathrm{AR}(2)$ fails to reject the null hypothesis of no autocorrelation. ${ }^{22}$ In Column 1, we again find that $\mathrm{AID}_{i t}$ has no significant effect on $\mathrm{GROWTH}_{i t}$ on average, i.e., when excluding the interaction term. Our main GMM specification in Column 2 suggests again that the effect of $\mathrm{AID}_{i t}$ on $\mathrm{GROWTH}_{i t}$ is significant in ethnically homogenous countries, but decreases as countries become more ethnically fractionalised. Figure 2 presents the implied effect of $\mathrm{AID}_{i t}$ on $\mathrm{GROWTH}_{i t}$ and the associated standard errors for all possible levels of ETHNIC $i$. Like our 2SLS estimates, our GMM estimates suggest that the effect of $\mathrm{AID}_{i t}$ on $\mathrm{GROWTH}_{i t}$ is significantly positive at low levels of ETHNIC $i$. But unlike our 2SLS estimates, our GMM estimates further suggest that this effect is significantly negative at high levels of ETHNIC $i$. They also imply somewhat lower threshold levels of $\mathrm{ETHNIC}_{i}$. In particular, the point estimates suggest that the indirect negative effects of foreign aid may offset its direct positive effects in considerably more than half of the countries in Sub-Saharan Africa as well as in some fractionalised countries in Latin America and elsewhere. ${ }^{23}$

In Column 3, we again exclude the $10 \%$ least and the $10 \%$ most ethnically fractionalised countries from our samples. In Column 4, we employ

22 The appropriate null hypothesis is absence of second-order autocorrelation because firstdifferencing of endogenous variables directly induces first-order autocorrelation.

23 The point estimates in Column 2 suggest a threshold level of 0.51. ETHNIC $i$ exceeds 0.51 in 58 of the 114 countries in our baseline sample, including 34 Sub-Saharan African and 10 Latin American countries. 
all possible lags of the endogenous variables as instruments starting from the second lag. In Column 5, we collapse the set of instruments using the method proposed by Roodman (2009). In all instances, the coefficients of interest show the predicted signs and remain highly significant. In Column 6, we show that the coefficients of interest have the predicted signs and are close to being significant even when using the difference-GMM estimator. In addition, we again show in Column 7 , that $\mathrm{AID}_{i t}$ and $\mathrm{AID}_{i t} \times \mathrm{ETHNIC}_{i}$ have similar effects on investment as they have on economic growth.

In the remainder of this section we present further robustness exercises based on the 2SLS regression of Column 4 of Table 2, and the system-GMM regression of Column 2 of Table 3. We have argued before that our bareboned baseline specification is appropriate to test how ethnic fractionalisation impacts upon aid effectiveness through all possible channels. Nevertheless, we look whether our results are robust to the addition of further control variables. We start by adding a measure of trade openness $\left(\mathrm{TRADE}_{i t}\right)$ to our baseline specification in all columns of Table 4 , as a considerable share of aid inflows is typically used to finance imports. We then add geographical variables, namely distance from the equator $\left(\right.$ LATITUDE $_{i}$ ) and the fraction of a country's area located in the tropics $\left(\right.$ TROPICS $\left._{i}\right)$. As a next step, we further control for institutional quality by adding the indices of political rights $\left(\right.$ POLITICAL $\left._{i t}\right)$ and civil liberties $\left(\mathrm{CIVIL}_{i t}\right)$ from Freedom House, which are both inverse measures of institutional quality. In a further step, we include investment $\left(\mathrm{INV}_{i t}\right)$, which is a particularly close determinant of economic growth. Finally, we add government expenditures $\left(\mathrm{GOV}_{i t}\right)$ as a measure of fiscal policies. We find that the coefficients on $\mathrm{AID}_{i t}$ and the interaction term still show the predicted signs and remain statistically significant at least at the $10 \%$ level, while all control variables other than investment are generally insignificant. ${ }^{24}$

In Table 5, we test whether our results are robust to the use of alternative measures of foreign aid. We replace $\mathrm{AID}_{i t}$ by the two ODA-based aid measures $\mathrm{ODA}_{i t}^{R}$ and $\mathrm{ODA}_{i t}^{X}$ in our baseline 2SLS and GMM regressions. We note that the coefficients on these aid measures and their interactions with $\mathrm{ETHNIC}_{i}$ have the predicted signs and are statistically significant in all four regressions, except that $\mathrm{ODA}_{i t}^{X} \times \mathrm{ETHNIC}_{i}$ is marginally insignificant in Column 3.

${ }^{24}$ Not surprisingly, the GMM results also continue to hold when controlling for the timeinvariant geographical variables LATITUDE $_{i}$ and TROPICS . $_{\text {. }}$ 
Table 4: Additional Control Variables

\begin{tabular}{|c|c|c|c|c|c|c|c|c|c|}
\hline & $\begin{array}{l}\text { (1) } \\
2 S L S\end{array}$ & $\begin{array}{l}\text { (2) } \\
2 S L S\end{array}$ & $\begin{array}{l}\text { (3) } \\
2 S L S\end{array}$ & $\begin{array}{l}(4) \\
2 S L S\end{array}$ & $\begin{array}{l}\text { (5) } \\
2 S L S\end{array}$ & $\begin{array}{l}\text { (6) } \\
\text { GMM }\end{array}$ & $\begin{array}{l}\text { (7) } \\
\text { GMM }\end{array}$ & $\begin{array}{l}\text { (8) } \\
\text { GMM }\end{array}$ & $\begin{array}{l}\text { (9) } \\
\text { GMM }\end{array}$ \\
\hline $\mathrm{AID}_{i t}$ & $\begin{array}{c}1.204 \\
(0.060)\end{array}$ & $\begin{array}{c}2.894 \\
(0.050)\end{array}$ & $\begin{array}{c}2.775 \\
(0.030)\end{array}$ & $\begin{array}{c}2.771 \\
(0.029)\end{array}$ & $\begin{array}{c}2.676 \\
(0.063)\end{array}$ & $\begin{array}{c}0.693 \\
(0.018)\end{array}$ & $\begin{array}{c}0.524 \\
(0.075)\end{array}$ & $\begin{array}{c}0.453 \\
(0.102)\end{array}$ & $\begin{array}{c}0.541 \\
(0.058)\end{array}$ \\
\hline ETHNIC $_{i}$ & $\begin{array}{c}-0.007 \\
(0.604)\end{array}$ & $\begin{array}{c}0.025 \\
(0.316)\end{array}$ & $\begin{array}{c}0.028 \\
(0.253)\end{array}$ & $\begin{array}{c}0.027 \\
(0.257)\end{array}$ & $\begin{array}{c}0.026 \\
(0.330)\end{array}$ & & & & \\
\hline AID $_{i t} * \mathrm{ETHNIC}_{i}$ & $\begin{array}{r}-1.655 \\
(0.076)\end{array}$ & $\begin{array}{c}-3.819 \\
(0.058)\end{array}$ & $\begin{array}{r}-3.657 \\
(0.033)\end{array}$ & $\begin{array}{r}-3.678 \\
(0.030)\end{array}$ & $\begin{array}{c}-3.472 \\
(0.062)\end{array}$ & $\begin{array}{c}-1.508 \\
(0.002)\end{array}$ & $\begin{array}{c}-1.293 \\
(0.006)\end{array}$ & $\begin{array}{r}-1.137 \\
(0.013)\end{array}$ & $\begin{array}{r}-1.172 \\
(0.009)\end{array}$ \\
\hline TRADE $_{i t}$ & $\begin{array}{c}0.002 \\
(0.482)\end{array}$ & $\begin{array}{c}-0.003 \\
(0.652)\end{array}$ & $\begin{array}{c}-0.004 \\
(0.597)\end{array}$ & $\begin{array}{c}-0.006 \\
(0.377)\end{array}$ & $\begin{array}{c}-0.004 \\
(0.557)\end{array}$ & $\begin{array}{c}0.007 \\
(0.196)\end{array}$ & $\begin{array}{c}0.011 \\
(0.041)\end{array}$ & $\begin{array}{c}0.006 \\
(0.196)\end{array}$ & $\begin{array}{c}0.005 \\
(0.285)\end{array}$ \\
\hline LATITUDE $_{i}$ & & $\begin{array}{c}0.000 \\
(0.513)\end{array}$ & $\begin{array}{c}0.001 \\
(0.428)\end{array}$ & $\begin{array}{c}0.000 \\
(0.541)\end{array}$ & $\begin{array}{c}0.000 \\
(0.510)\end{array}$ & & & & \\
\hline TROPICS $_{i}$ & & $\begin{array}{r}-0.003 \\
(0.829)\end{array}$ & $\begin{array}{c}-0.002 \\
(0.924)\end{array}$ & $\begin{array}{c}-0.001 \\
(0.933)\end{array}$ & $\begin{array}{c}-0.003 \\
(0.853)\end{array}$ & & & & \\
\hline POLITICAL $_{i t}$ & & & $\begin{array}{c}-0.002 \\
(0.499)\end{array}$ & $\begin{array}{c}-0.002 \\
(0.455)\end{array}$ & $\begin{array}{c}-0.002 \\
(0.427)\end{array}$ & & $\begin{array}{c}-0.003 \\
(0.157)\end{array}$ & $\begin{array}{c}-0.002 \\
(0.210)\end{array}$ & $\begin{array}{c}-0.002 \\
(0.229)\end{array}$ \\
\hline $\mathrm{CIVIL}_{i t}$ & & & $\begin{array}{c}0.002 \\
(0.603)\end{array}$ & $\begin{array}{c}0.002 \\
(0.523)\end{array}$ & $\begin{array}{c}0.002 \\
(0.504)\end{array}$ & & $\begin{array}{c}0.002 \\
(0.530)\end{array}$ & $\begin{array}{c}0.002 \\
(0.389)\end{array}$ & $\begin{array}{c}0.002 \\
(0.471)\end{array}$ \\
\hline $\mathrm{INV}_{i t}$ & & & & $\begin{array}{c}0.047 \\
(0.112)\end{array}$ & $\begin{array}{c}0.045 \\
(0.134)\end{array}$ & & & $\begin{array}{c}0.091 \\
(0.001)\end{array}$ & $\begin{array}{c}0.092 \\
(0.001)\end{array}$ \\
\hline $\mathrm{GOV}_{i t}$ & & & & & $\begin{array}{c}-0.039 \\
(0.249)\end{array}$ & & & & $\begin{array}{c}-0.032 \\
(0.162)\end{array}$ \\
\hline $\mathrm{GDP}_{i t}$ & YES & YES & YES & YES & YES & YES & YES & YES & YES \\
\hline Year dummies & YES & YES & YES & YES & YES & YES & YES & YES & YES \\
\hline Regional dummies & YES & YES & YES & YES & YES & NO & NO & NO & NO \\
\hline Implied threshold $-\beta_{1} / \beta_{3}$ & 0.73 & 0.76 & 0.76 & 0.75 & 0.77 & 0.46 & 0.41 & $(0.40)$ & 0.46 \\
\hline
\end{tabular}


Table 4: Continued

\begin{tabular}{|c|c|c|c|c|c|c|c|c|c|}
\hline & $\begin{array}{l}(1) \\
2 S L S\end{array}$ & $\begin{array}{l}\text { (2) } \\
2 S L S\end{array}$ & $\begin{array}{l}\text { (3) } \\
\text { 2SLS }\end{array}$ & $\begin{array}{l}\text { (4) } \\
2 S L S\end{array}$ & $\begin{array}{l}\text { (5) } \\
2 S L S\end{array}$ & $\begin{array}{l}\text { (6) } \\
\text { GMM }\end{array}$ & $\begin{array}{l}\text { (7) } \\
\text { GMM }\end{array}$ & $\begin{array}{l}\text { (8) } \\
\text { GMM }\end{array}$ & $\begin{array}{l}\text { (9) } \\
\text { GMM }\end{array}$ \\
\hline Countries & 763 & 696 & 591 & 591 & 591 & 763 & 656 & 656 & 656 \\
\hline Observations & 114 & 93 & 93 & 93 & 93 & 114 & 114 & 114 & 114 \\
\hline$R^{2}$ & 0.222 & 0.173 & 0.161 & 0.169 & 0.174 & - & - & - & - \\
\hline Hansen J-test ( $p$-value) & 0.242 & 0.370 & 0.282 & 0.174 & 0.114 & 0.467 & 0.489 & 0.495 & 0.436 \\
\hline $\operatorname{AR}(2)$ test ( $p$-value) & - & - & -- & - & - & 0.531 & 0.754 & 0.834 & 0.851 \\
\hline GMM instrument count & - & - & & - & - & 57 & 57 & 58 & 59 \\
\hline
\end{tabular}

Notes: Dependent variable is GROWTH ${ }_{i t} . p$-values in parentheses are based on robust and clustered standard errors in $2 \mathrm{SLS}$ regressions, and on robust standard errors and the Windmeijer (2005) finite-sample correction in GMM regressions. In GMM regressions, system-GMM is used with the second and third lags of the endogenous variables as instruments. In all columns, exogenous variables used as instruments are $\mathrm{FRZ}_{i}, \mathrm{CAM}_{i}$, $\mathrm{EGY}_{i}, \mathrm{POP}_{i t}, \mathrm{POP}_{i t}^{2}, \mathrm{POP}_{i t}{ }^{*} \mathrm{ETHNIC}_{i}, \mathrm{ARMS}_{i t}, \mathrm{ARMS}_{i t}^{2}$ and $\mathrm{ARMS}_{i t}$ *ETHNIC . 
Table 5: Alternative Measures of Aid

\begin{tabular}{|c|c|c|c|c|}
\hline & $\begin{array}{l}(1) \\
2 S L S\end{array}$ & $\begin{array}{l}\text { (2) } \\
\text { GMM }\end{array}$ & $\begin{array}{l}\text { (3) } \\
2 S L S\end{array}$ & $\begin{array}{l}\text { (4) } \\
\text { GMM }\end{array}$ \\
\hline $\mathrm{ODA}_{i t}^{R}$ & $\begin{array}{c}0.771 \\
(0.037)\end{array}$ & $\begin{array}{c}0.450 \\
(0.003)\end{array}$ & & \\
\hline $\mathrm{ODA}_{i t}^{X}$ & & & $\begin{array}{c}0.354 \\
(0.063)\end{array}$ & $\begin{array}{c}0.162 \\
(0.015)\end{array}$ \\
\hline ETHNIC $_{i}$ & $\begin{array}{r}-0.006 \\
(0.659)\end{array}$ & & $\begin{array}{r}-0.002 \\
(0.897)\end{array}$ & \\
\hline $\mathrm{ODA}_{i t}^{R} * \mathrm{ETHNIC}_{i}$ & $\begin{array}{r}-0.938 \\
(0.068)\end{array}$ & $\begin{array}{c}-0.994 \\
(0.001)\end{array}$ & & \\
\hline $\mathrm{ODA}_{i t}^{X}{ }^{*} \mathrm{ETHNIC}_{i}$ & & & $\begin{array}{c}-0.444 \\
(0.103)\end{array}$ & $\begin{array}{c}-0.193 \\
(0.019)\end{array}$ \\
\hline $\mathrm{GDP}_{i t}$ & YES & YES & YES & YES \\
\hline Year dummies & YES & YES & YES & YES \\
\hline Regional dummies & YES & NO & YES & NO \\
\hline Implied threshold $-\beta_{1} / \beta_{3}$ & 0.82 & 0.45 & $(0.80)$ & 0.84 \\
\hline Countries & 114 & 114 & 114 & 114 \\
\hline Observations & 763 & 763 & 748 & 748 \\
\hline$R^{2}$ & 0.215 & - & 0.208 & - \\
\hline Hansen J-test ( $p$-value) & 0.341 & 0.389 & 0.330 & 0.489 \\
\hline $\operatorname{AR}(2)$ test ( $p$-value) & - & 0.924 & - & 0.596 \\
\hline GMM instrument count & - & 66 & - & 66 \\
\hline
\end{tabular}

Notes: Dependent variable is GROWTH ${ }_{i t} . p$-values in parentheses are based on robust and clustered standard errors in 2SLS regressions, and on robust standard errors and the Windmeijer (2005) finite-sample correction in GMM regressions. In GMM regressions, system-GMM is used with the second and third lags of the endogenous variables as instruments. In all columns, exogenous variables used as instruments are $\mathrm{FRZ}_{i}, \mathrm{CAM}_{i}, \mathrm{EGY}_{i}$, $\mathrm{POP}_{i t}, \mathrm{POP}_{i t}^{2} \mathrm{POP}_{i t}{ }^{*} \mathrm{ETHNIC}_{i}, \mathrm{ARMS}_{i t}, \mathrm{ARMS}_{i t}^{2}$ and $\mathrm{ARMS}_{i t}{ }^{*} \mathrm{ETHNIC}_{i}$.

In Table 6, we test whether our results are robust to the use of alternative measures of diversity and fractionalisation, as well as when addressing the potential endogeneity of ethnic fractionalisation. Our baseline specification assumes that the effect of ethnic fractionalisation on aid effectiveness is linear. We test for potential non-linearities by using a set of dummy variables indicating the quintiles of the distribution of ETHNIC $_{i}$. We construct the dummy variables QUINTILE $k_{i}$ for $k=1,2,3,4$, 5, where QUINTILE $k_{i}=1$ if and only if ETHNIC $_{i}$ belongs to the $k$ th quintile of ETHNIC $_{i}$. In Columns 1 and 2, we use these dummy variables and their interactions with $\mathrm{AID}_{i t}$. The 2SLS and GMM point estimates suggest that the effect of ethnic fractionalisation on aid effectiveness is indeed linear 
Table 6: Alternative Measures and Instruments for Fractionalisation

\begin{tabular}{|c|c|c|c|c|c|c|c|c|}
\hline & $\begin{array}{l}\text { (1) } \\
2 S L S\end{array}$ & $\begin{array}{l}\text { (2) } \\
\text { GMM }\end{array}$ & $\begin{array}{l}\text { (3) } \\
2 S L S\end{array}$ & $\begin{array}{l}\text { (4) } \\
\text { GMM }\end{array}$ & $\begin{array}{l}\text { (5) } \\
2 S L S\end{array}$ & $\begin{array}{l}\text { (6) } \\
\text { GMM }\end{array}$ & $\begin{array}{l}\text { (7) } \\
2 S L S\end{array}$ & $\begin{array}{l}\text { (8) } \\
\text { GMM }\end{array}$ \\
\hline AID $_{i t} *$ QUINTILE1 ${ }_{i}$ & $\begin{array}{c}1.195 \\
(0.089)\end{array}$ & $\begin{array}{l}0.230 \\
(0.463)\end{array}$ & & & & & & \\
\hline AID $_{i t} *$ QUINTILE2 $_{i}$ & $\begin{array}{c}1.136 \\
(0.035)\end{array}$ & $\begin{array}{c}0.212 \\
(0.202)\end{array}$ & & & & & & \\
\hline AID $_{i t} *$ QUINTILE3 $_{i}$ & $\begin{array}{c}0.292 \\
(0.360)\end{array}$ & $\begin{array}{c}0.132 \\
(0.567)\end{array}$ & & & & & & \\
\hline AID $_{i t} *$ QUINTILE $_{i}$ & $\begin{array}{c}0.149 \\
(0.830)\end{array}$ & $\begin{array}{c}-0.190 \\
(0.431)\end{array}$ & & & & & & \\
\hline AID $_{i t} *$ QUINTILE5 $_{i}$ & $\begin{array}{c}-0.134 \\
(0.576)\end{array}$ & $\begin{array}{c}-0.411 \\
(0.117)\end{array}$ & & & & & & \\
\hline $\operatorname{AID}_{i t}$ & & & $\begin{array}{c}0.349 \\
(0.222)\end{array}$ & $\begin{array}{c}0.160 \\
(0.431)\end{array}$ & $\begin{array}{c}0.444 \\
(0.063)\end{array}$ & $\begin{array}{c}0.012 \\
(0.934)\end{array}$ & $\begin{array}{c}2.331 \\
(0.033)\end{array}$ & $\begin{array}{c}0.951 \\
(0.009)\end{array}$ \\
\hline LANGUAGE $_{i}$ & & & $\begin{array}{c}-0.017 \\
(0.133)\end{array}$ & & & & & \\
\hline $\operatorname{AID}_{i t}{ }^{*}$ LANGUAGE $_{i}$ & & & $\begin{array}{c}-0.431 \\
(0.316)\end{array}$ & $\begin{array}{r}-0.653 \\
(0.057)\end{array}$ & & & & \\
\hline RELIGION $_{i}$ & & & & & $\begin{array}{l}0.016 \\
(0.261)\end{array}$ & & & \\
\hline $\operatorname{AID}_{i t} * \mathrm{RELIGION}_{i}$ & & & & & $\begin{array}{c}-0.509 \\
(0.443)\end{array}$ & $\begin{array}{r}-0.067 \\
(0.819)\end{array}$ & & \\
\hline ETHNIC $_{i}$ & & & & & & & $\begin{array}{l}0.029 \\
(0.357)\end{array}$ & \\
\hline $\mathrm{AID}_{i t}{ }^{*} \mathrm{ETHNIC}_{i}$ & & & & & & & $\begin{array}{r}-3.180 \\
(0.067)\end{array}$ & $\begin{array}{r}-1.750 \\
(0.005)\end{array}$ \\
\hline
\end{tabular}




\begin{tabular}{|c|c|c|c|c|c|c|c|c|}
\hline $\mathrm{GDP}_{i t}$ & YES & YES & YES & YES & YES & YES & YES & YES \\
\hline Year dummies & YES & YES & YES & YES & YES & YES & YES & YES \\
\hline Regional dummies & YES & NO & YES & NO & YES & NO & YES & NO \\
\hline Quintile dummies & YES & NO & NO & NO & NO & NO & NO & NO \\
\hline Implied threshold $-\beta_{1} / \beta_{3}$ & - & - & $(0.81)$ & $(0.25)$ & $(0.87)$ & $(0.18)$ & 0.73 & 0.54 \\
\hline Countries & 114 & 114 & 108 & 108 & 114 & 114 & 93 & 93 \\
\hline Observations & 763 & 763 & 736 & 736 & 763 & 763 & 681 & 681 \\
\hline$R^{2}$ & 0.177 & - & 0.223 & - & 0.172 & - & 0.263 & - \\
\hline Hansen $J$-test ( $p$-value) & 0.117 & 0.517 & 0.478 & 0.738 & 0.255 & 0.301 & 0.408 & 0.475 \\
\hline $\operatorname{AR}(2)$ test ( $p$-value) & - & 0.940 & - & 0.964 & - & 0.937 & & 0.840 \\
\hline GMM instrument count & - & 116 & - & 56 & - & 56 & & 56 \\
\hline
\end{tabular}

Notes: Dependent variable is GROWTH ${ }_{i t} . p$-values in parentheses are based on robust and clustered standard errors in 2SLS regressions, and on robust standard errors and the Windmeijer (2005) finite-sample correction in GMM regressions. In GMM regressions, system-GMM is used with the second and third lags of the endogenous variables as instruments. In all columns, exogenous variables used as instruments include FRZ ${ }_{i}$, $\mathrm{CAM}_{i}, \mathrm{EGY}_{i}, \mathrm{POP}_{i t}^{2}$ and $\mathrm{ARMS}_{i t}^{2}$. In addition, the interactions of POP $i t$ and ARMS $i t$ with each of the quintile dummies are used in Columns 1-2;

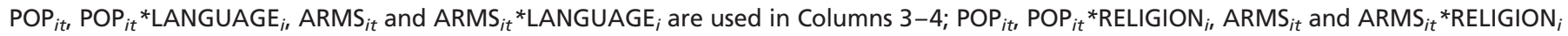

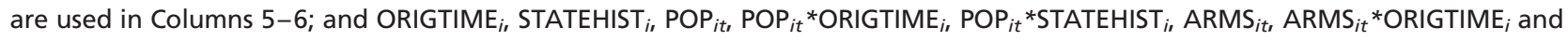
ARMS $_{i t}$ *STATEHIST $i$ are used in Columns 7-8. 
or, at least, monotonic. ${ }^{25}$ While most of the interaction terms are statistically insignificant, the difference between $\operatorname{AID}_{i t} \times$ QUINTILE $_{i}$ and $\mathrm{AID}_{i t} \times$ QUINTILE5 $_{i}$ is statistically significant at the $10 \%$ level in both columns. This significant difference suggests that foreign aid is indeed more effective in promoting economic growth in the ethnically least fractionalised countries than in the ethnically most fractionalised countries.

In Columns 3 to 6, we replace $\mathrm{ETHNIC}_{i}$ by the indices of linguistic and religious fractionalisation (LANGUAGE $i$ and RELIGION ${ }_{i}$ ). The coefficients on $\mathrm{AID}_{i t}$ and its interaction with these indices still show the predicted signs, but most of them are relatively close to zero and statistically insignificant. These results suggest that the hypothesised rent-seeking contests for aid inflows mainly occur along ethnic lines rather than religious or purely linguistic lines. ${ }^{26}$ Caselli and Coleman (2006) provide a plausible explanation for such a pattern. They present a model in which conflicts over resources, say aid inflows, emerge if winners can easily identify losers and prevent them from infiltration when it comes to sharing the spoils of victory. They argue that not all distinctions are equally effective ways of ensuring that group members can be identified, with differences in physical appearance being more infiltration-proof than linguistic or religious differences.

While the empirical literature has so far assumed ethnic diversity to be exogenous, Ahlerup and Olsson (2011) show that ethnic fractionalisation is systematically related to the duration of human settlement since prehistoric times $\left(\mathrm{ORIGTIME}_{i}\right.$ ), and to Putterman's (2007) State Antiquity Index $\left(\mathrm{STATEHIST}_{i}\right)$. This index measures the extent to which a political entity above the tribal level existed in the state's present territory in the years 1 to 1950 C.E. In Columns 7 and 8, we therefore address the potential endogeneity of ethnic fractionalisation by employing ORIGTIME $_{i}$ and STATEHIST $_{i}$ and their interactions with ARMS $i t$ and $\mathrm{POP}_{i t}$ as instruments for $\mathrm{ETHNIC}_{i}$ and its interaction with $\mathrm{AID}_{i t}$. The coefficients of interest still show the predicted signs and retain their statistical significance. ${ }^{27}$

25 That is, the coefficient on $\mathrm{AID}_{i t} \times$ QUINTILE $m_{i}$ is strictly higher than the coefficient on $\mathrm{AID}_{i t} \times$ QUINTILE $n_{i}$ if and only if $m<n$.

${ }^{26}$ As mentioned in footnote 3, the theoretical models of Svensson (2000) and Hodler (2006) are in principle silent about the relevant dividing lines between rivalling groups. The insignificant results in Columns 3-6 of Table 6, however, support their emphasis on rivalling groups that are separated along ethnic lines.

27 When adding ORIGTIME $i$ and STATEHIST $_{i}$ and their interactions with AID $_{i t}$ as additional control variables in the second-stage regression (while taking ETHNIC $_{i}$ as exogenous), our coefficients of interest still show the expected signs, but become 
In Table 7, we compare our hypothesis to other findings and hypotheses advanced in the conditional aid effectiveness literature. We thereby focus on the finding of Hansen and Tarp $(2000,2001)$ that there are decreasing returns to aid; the finding of Dalgaard et al. (2004) that aid is more effective outside the tropics; and the finding of Angeles and Neanidis (2009) that aid is more effective in countries with few colonial settlers and, therefore, no overly strong elite. In Columns 1 and 2, we add aid squared $\left(\mathrm{AID}_{i t}^{2}\right)$ to our baseline 2SLS and GMM regressions. We note that the coefficients on $\mathrm{AID}_{i t}$ and $\mathrm{AID}_{i t} \times \mathrm{ETHNIC}_{i}$ retain the predicted signs and their statistical significance, while the coefficient on $\mathrm{AID}_{i t}^{2}$ is significant in Column 2, but not in Column 1. These results provide further support for our hypothesis. They moreover suggest that earlier studies may have found robust evidence for the hypothesis of decreasing returns to aid partly because more fractionalised countries (paradoxically) tend to receive more aid (with the correlation between $\mathrm{AID}_{i t}$ and $\mathrm{ETHNIC}_{i}$ being 0.25).

To compare our hypothesis to the finding of Dalgaard et al. (2004), we add the interaction term AID $_{i t} \times$ TROPICS $_{i}$ in Columns 3 and 4 . Since we need to instrument also for this interaction term, we add $\mathrm{ARMS}_{i t} \times$ TROPICS $_{i}$ and $\mathrm{POP}_{i t} \times$ TROPICS$_{i}$ to the set of our instruments. Again, the coefficients on $\mathrm{AID}_{i t}$ and $\mathrm{AID}_{i t} \times \mathrm{ETHNIC}_{i}$ retain the predicted signs and their statistical significance at the $10 \%$ level. The interaction term $\mathrm{AID}_{i t} \times$ TROPICS $_{i}$ has the expected sign and is statistically significant in column (4), but not in Column 3. While the high correlation between TROPICS $_{i}$ and ETHNIC $i, 0.53$, tends to inflate the standard errors of our estimates; these results still allow us to conclude that we are not just picking up an effect of TROPICS $_{i}$ on aid effectiveness, but a robust and independent effect of $\mathrm{ETHNIC}_{i}$ on aid effectiveness.

We finally compare our hypothesis to the findings of Angeles and Neanidis (2009). In Columns 5 and 6, we add an interaction term between $\mathrm{AID}_{i t}$ and the share of colonial settlers $\left(\right.$ SETTLERS $\left._{i}\right)$, i.e., the share of the population that was of European origin in colonial times, to our baseline 2SLS and GMM regressions, and we adjust the set of instruments accordingly. We find that the coefficients on $\operatorname{AID}_{i t}, \operatorname{AID}_{i t} \times$ ETHNIC $_{i}$ and $\mathrm{AID}_{i t} \times \mathrm{SETTLERS}_{i}$ all have the predicted signs and are statistically significant. These results provide further support for our hypothesis as well as for the hypothesis of Angeles and Neanidis. Hence, foreign

statistically insignificant. This, however, is hardly surprising as the high correlation between $\mathrm{ETHNIC}_{i}$ and $\mathrm{ORIGTIME}_{i}$, which is 0.55 , tends to inflate the standard errors. 
Table 7: Alternative Determinants of Aid Effectiveness

\begin{tabular}{|c|c|c|c|c|c|c|}
\hline & $\begin{array}{l}\text { (1) } \\
2 S L S\end{array}$ & $\begin{array}{l}\text { (2) } \\
\text { GMM }\end{array}$ & $\begin{array}{l}\text { (3) } \\
2 S L S\end{array}$ & $\begin{array}{l}\text { (4) } \\
\text { GMM }\end{array}$ & $\begin{array}{l}\text { (5) } \\
2 S L S\end{array}$ & $\begin{array}{l}\text { (6) } \\
\text { GMM }\end{array}$ \\
\hline $\operatorname{AID}_{i t}$ & $\begin{array}{l}2.007 \\
(0.041)\end{array}$ & $\begin{array}{c}1.156 \\
(0.005)\end{array}$ & $\begin{array}{l}3.054 \\
(0.030)\end{array}$ & $\begin{array}{c}1.238 \\
(0.000)\end{array}$ & $\begin{array}{l}3.298 \\
(0.044)\end{array}$ & $\begin{array}{c}1.652 \\
(0.006)\end{array}$ \\
\hline ETHNIC $_{i}$ & $\begin{array}{r}-0.005 \\
(0.724)\end{array}$ & & $\begin{array}{c}0.032 \\
(0.292)\end{array}$ & & $\begin{array}{c}0.012 \\
(0.633)\end{array}$ & \\
\hline $\mathrm{AID}_{i t}{ }^{*} \mathrm{ETHNIC}_{i}$ & $\begin{array}{r}-1.662 \\
(0.080)\end{array}$ & $\begin{array}{c}-1.274 \\
(0.008)\end{array}$ & $\begin{array}{r}-4.888 \\
(0.069)\end{array}$ & $\begin{array}{r}-1.098 \\
(0.057)\end{array}$ & $\begin{array}{r}-4.319 \\
(0.050)\end{array}$ & $\begin{array}{r}-2.589 \\
(0.002)\end{array}$ \\
\hline $\mathrm{AID}_{i t}^{2}$ & $\begin{array}{r}-6.659 \\
(0.355)\end{array}$ & $\begin{array}{c}-4.071 \\
(0.085)\end{array}$ & & & & \\
\hline TROPICS $_{i}$ & & & $\begin{array}{c}-0.018 \\
(0.080)\end{array}$ & & & \\
\hline AID $_{i t} *$ TROPICS $_{i}$ & & & $\begin{array}{l}0.903 \\
(0.402)\end{array}$ & $\begin{array}{r}-0.865 \\
(0.000)\end{array}$ & & \\
\hline SETTLERS $_{i}$ & & & & & $\begin{array}{l}0.001 \\
(0.034)\end{array}$ & \\
\hline $\operatorname{AID}_{i t} *$ SETTLERS $_{i}$ & & & & & $\begin{array}{c}-7.831 \\
(0.028)\end{array}$ & $\begin{array}{r}-3.639 \\
(0.063)\end{array}$ \\
\hline$G D P_{i t}$ & YES & YES & YES & YES & YES & YES \\
\hline Year dummies & YES & YES & YES & YES & YES & YES \\
\hline Regional dummies & YES & NO & YES & NO & YES & NO \\
\hline Countries & 114 & 114 & 95 & 95 & 95 & 95 \\
\hline Observations & 763 & 763 & 710 & 710 & 699 & 699 \\
\hline$R^{2}$ & 0.250 & - & 0.090 & - & 0.225 & - \\
\hline Hansen $J$-test ( $p$-value) & 0.297 & 0.338 & 0.320 & 0.433 & 0.100 & 0.551 \\
\hline $\operatorname{AR}(2)$ test ( $p$-value) & - & 0.672 & - & 0.788 & - & 0.998 \\
\hline $\begin{array}{l}\text { GMM instrument } \\
\text { count }\end{array}$ & - & 74 & - & 76 & - & 76 \\
\hline
\end{tabular}

Notes: Dependent variable is $\mathrm{GROWTH}_{i t}$. $p$-values in parentheses are based on robust and clustered standard errors in 2SLS regressions, and on robust standard errors and the Windmeijer (2005) finite-sample correction in GMM regressions. In GMM regressions, system-GMM is used with the second and third lags of the endogenous variables as instruments. In all columns, exogenous variables used as instruments include $\mathrm{FRZ}_{i}, \mathrm{CAM}_{i}$, $\mathrm{EGY}_{i}, \mathrm{POP}_{i t}, \mathrm{POP}_{i t}^{2}, \mathrm{POP}_{i t}$ *ETHNIC $i, \mathrm{ARMS}_{i t}, \mathrm{ARMS}_{i t}^{2}$ and $\mathrm{ARMS}_{i t}{ }^{*} \mathrm{ETHNIC}_{i}$. In addition, POP $_{i t}$ *TROPICS $i$ and ARMS $_{i t}{ }^{*}$ TROPICS $_{i}$ are used in Columns 3-4; and POP $i t$ *SETTLERS $i$ and ARMS $_{i t}$ *SETTLERS $i$ are used in Columns 5-6.

aid becomes less effective when there are many rivalling groups as well as when there exists a strong elite of colonial settlers. These results are consistent with the idea that rent-seeking contests caused by aid inflows get more detrimental when the number of ethnic groups rises, as well as when the 
differences in physical appearance across the major ethnic groups grow larger.

\section{Conclusions}

Using panel data covering 114 aid-recipient countries over the period 1962 to 2001 , we find that foreign aid is effective in promoting economic growth in ethnically homogenous countries and that higher ethnic fractionalisation reduces aid effectiveness. Our estimates suggest that foreign aid may be ineffective or even harmful in many fractionalized countries, most of which are located in Sub-Saharan Africa. These findings are consistent with the hypothesis that there is a direct positive effect of foreign aid on economic growth, which is offset in fractionalised countries in which aid inflows may provoke detrimental rent-seeking contests.

Our findings have important implications for future foreign aid policy. They suggest that more focus should be placed on the degree of integration of distinct groups in a country. If a country is starkly fractionalised, fungible aid flows without conditions and close oversight may do more harm than good. A clearer view on practical methods that are effective in counteracting the negative side effects of aid in fractionalised countries would certainly benefit from further research on a more microeconomic level.

\section{Funding}

This study was support by the Department of Economics at the University of Melbourne.

\section{Acknowledgements}

We would like to thank Chris Doucouliagos, Manisha Shah and two anonymous referees for helpful comments, and Luis Angeles and Kyriakos Neanidis for sharing their data.

\section{References}

Acemoglu, D., J. A. Robinson and T. Verdier (2004) 'Kleptocracy and Divide-and-rule: A Model of Personal Rule', Journal of the European Economic Association, 2(2-3): 162-92. 
Ahlerup, P. and O. Olsson (2011) 'The Roots of Ethnic Diversity', Journal of Economic Growth, forthcoming.

Alesina, A., A. Devleeschauwer, W. Easterly and S. Kurlat (2003) 'Fractionalization', Journal of Economic Growth, 8(2): 155-94.

Alesina, A. and B. Weder (2002) 'Do Corrupt Governments Receive Less Foreign Aid?', American Economic Review, 92(4): 1126-37.

Angeles, L. and C. Neanidis (2009) 'Aid Effectiveness: The Role of the Local Elite', Journal of Development Economics, 90(1): 120-34.

Arellano, M. and S. Bond (1991) 'Some Tests of Specification for Panel Data: Monte Carlo Evidence and an Application to Employment Equations', Review of Economic Studies, 58(194): 277-97.

Bjørnskov, C. (2009) 'Do Elites Benefit from Democracy and Foreign Aid in Developing Countries?', Journal of Development Economics, 92(2): 115-24.

Blundell, R. and S. Bond (1998) 'Initial Conditions and Moment Restrictions in Dynamic Panel Data Models', Journal of Econometrics, 87(1): 115-43.

Boone, P. (1996) 'Politics and the Effectiveness of Foreign Aid', European Economic Review, 40(2): 289-329.

Brambor, T., W. S. Clark and M. Golder (2006) 'Understanding Interaction Models: Improving Empirical Analyses', Political Analysis, 14: 63-82.

Bräutigam, D. A. and S. Knack (2004) 'Foreign Aid, Institutions, and Governance in Sub-Saharan Africa', Economic Development and Cultural Change, 52(2): $255-85$.

Burnside, C. and D. Dollar (2000) 'Aid, Policies, and Growth', American Economic Review, 90(4): 847-68.

Caselli, F. and J. W. Coleman II (2006) On the Theory of Ethnic Conflict, NBER Working Paper No. 12125. Cambridge, MA: National Bureau of Economic Research.

Chang, C. C., E. Fernandez-Arias and L. Serven (1998) Measuring Aid Flows: A New Approach, World Bank Policy Research Paper No. 387. Washington, D.C.: World Bank.

Dalgaard, C. J. and H. Hansen (2001) 'On Aid, Growth and Good Policies', Journal of Development Studies, 37(6): 17-41.

Dalgaard, C. J., H. Hansen and F. Tarp (2004) 'On the Empirics of Foreign Aid and Growth', Economic Journal, 114(496): F191-F216.

Dalgaard, C. J. and O. Olsson (2008) 'Windfall Gains, Political Economy and Economic Development', Journal of African Economies, 17(1): 72-109.

Djankov, S., J. G. Montalvo and M. Reynal-Querol (2008) 'The Curse of Aid', Journal of Economic Growth, 13(3): 169-94.

Doucouliagos, H. and M. Paldam (2008) 'Aid Effectiveness on Growth: A Meta Study', European Journal of Political Economy, 24(1): 1-24.

Doucouliagos, H. and M. Paldam (2010) 'Conditional Aid Effectiveness: A Meta-study', Journal of International Development, 22(4): 391-410. 
Easterly, W. and R. Levine (1997) 'Africa's Growth Tragedy: Policies and Ethnic Divisions', Quarterly Journal of Economics, 112(4): 1203-50.

Easterly, W., R. Levine and D. Roodman (2004) 'Aid, Policies and Growth: Comment', American Economic Review, 94(3): 774-80.

Gallup, J., J. Sachs and D. Mellinger (1999) 'Geography and Economic Development', International Regional Science Review, 22(2): 179-232.

Hadi, A. (1992) 'Identifying Multiple Outliers in Multivariate Data', Journal of the Royal Statistical Society, B(54): 761-77.

Hansen, H. and F. Tarp (2000) 'Aid Effectiveness Disputed', Journal of International Development, 12(3): 375-98.

Hansen, H. and F. Tarp (2001) 'Aid and Growth Regressions', Journal of Development Economics, 64(2): 547-70.

Hodler, R. (2006) 'The Curse of Natural Resources in Fractionalized Countries', European Economic Review, 50(6): 1367-86.

Hodler, R. (2007) 'Rent Seeking and Aid Effectiveness', International Tax and Public Finance, 14(5): 525-41.

Jensen, P. S. and M. Paldam (2006) 'Can the Two New Aid-Growth Models Be Replicated?', Public Choice, 127(1-2): 147-75.

Knack, S. (2001) 'Aid Dependence and the Quality of Governance: Cross-country Empirical Tests', Southern Economic Journal, 68(2): 310-29.

La Porta, R., F. Lopez-de-Silanes, A. Shleifer and R. Vishny (1999) 'The Quality of Government', Journal of Law, Economics and Organisation, 15(1): 222-79.

Lane, P. R. and A. Tornell (1996) 'Power, Growth and the Voracity Effect', Journal of Economic Growth, 1(2): 213-41.

Lensink, R. and H. White (2001) 'Are There Negative Returns to Aid?' Journal of Development Studies, 37(6): 42-65.

Miguel, E. and M. K. Guerty (2005) 'Ethnic Diversity, Social Sanctions, and Public Goods in Kenya', Journal of Public Economics, 89(11-12): 2325-68.

Ovaska, T. (2003) 'The Failure of Development Aid', Cato Journal, 23(2): 175-88.

Putterman, L. (2007) 'State Antiquity Index (Statehist)', http://www.econ.brown. edu/fac/Louis $\backslash$ Putterman.

Rajan, R. G. and A. Subramanian (2008) 'Aid and Growth: What Does the Cross-country Evidence Really Show?' Review of Economics and Statistics, 90(4): 643-65.

Reno, W. (1995) Corruption and State Politics in Sierra Leone. Cambridge: Cambridge University Press.

Rodrik, D. (2003) In Search of Prosperity. Princeton: Princeton University Press.

Roodman, D. (2004) The Anarchy of Numbers: Aid, Development, and Cross-country Empirics, Center for Global Development Working Paper 32. Washington, D.C.: Center for Global Development.

Roodman, D. (2007) 'The Anarchy of Numbers: Aid, Development, and Cross-country Empirics', World Bank Economic Review, 21(2): 255-77. 
Roodman, D. (2009) 'How to Do xtabond2: An Introduction to Difference and System GMM in Stata', Stata Journal, 9(1): 86-136.

Sachs, J. (2005) The End of Poverty: Economic Possibilities for Our Time. New York: Penguin Books.

Svensson, J., 2000. 'Foreign Aid and Rent-seeking', Journal of International Economics, 51(2): 437-61.

Tornell, A. and P. R. Lane (1999) 'The Voracity Effect', American Economic Review, 89(1): $22-46$.

Windmeijer, F. (2005) 'A Finite Sample Correction for the Variance of Linear Efficient Two-step GMM Estimators', Journal of Econometrics, 126(1): 25-51.

Wrong, M. (2009) It's Our Turn to Eat: The Story of a Kenyan Whistle-Blower. London: Fourth Estate.

\section{Appendix A: Data description}

$\mathrm{AID}_{i t}$ : Constant price effective development assistance relative to constant price PPP-adjusted GDP, averaged over the years $t$ to $t+3$. Source: Roodman (2004)

ARMS $_{i t}$ : Arms imports in US\$ divided by current-price PPP-adjusted GDP, averaged over the years $t$ to $t+3$. Source: SIPRI Arms Transfers Database and Penn World Tables

$\mathrm{CAM}_{i}$ : Dummy variable equal to 1 for Central American countries. Source: Roodman (2004)

CIVIL $_{i t}$ : Index of civil liberties, ranging from 1 to 7 , with higher values indicating less liberties, averaged over the years $t$ to $t+3$. Source: Freedom House

EGYPT $_{i}$ : Dummy variable equal to 1 for Egypt. Source: Roodman (2004) ETHNIC $_{i}$ : Index of ethnic fractionalization. Source: Alesina et al. (2003) FRZ $i$ : Dummy variable equal to 1 for member countries of the Franc Zone. Source: Roodman (2004)

$\mathrm{GDP}_{i t}$ : Constant price PPP-adjusted per capita GDP in year $t$. Source: Roodman (2004)

$\mathrm{GOV}_{i t}$ : Constant price PPP-adjusted government expenditures as a share of GDP, averaged over the years $t$ to $t+3$. Source: Penn World Table 6.3

GROWTH $_{i t}$ : Growth rate of constant price PPP-adjusted per capita GDP, averaged over the years $t$ to $t+3$. Source: Roodman (2004)

$\mathrm{INV}_{i t}$ : Constant price PPP-adjusted investment as a share of GDP, averaged over the years $t$ to $t+3$. Source: Penn World Table 6.3

LANGUAGE $_{i}$ : Index of linguistic fractionalization. Source: Alesina et al. (2003) 
LATITUDE $_{i}$ : Absolute latitude. Source: Gallup et al. (1999)

$\mathrm{ODA}_{i t}^{R}$ : Constant price net overseas development assistance relative to constant price PPP-adjusted GDP, averaged over the years $t$ to $t+3$. Source: Roodman (2004)

$\mathrm{ODA}_{i t}^{X}$ : Constant price net overseas development assistance relative to constant price GDP converted to US\$ on an exchange rate basis, averaged over the years $t$ to $t+3$. Source: Roodman (2004)

ORIGTIME $_{i}$ : Duration of human settlement. Source: Ahlerup and Olsson (2011)

POLITICAL ${ }_{i t}$ : Index of political rights, ranging from 1 to 7 , with higher values indicating less rights, averaged over the years $t$ to $t+3$. Source: Freedom House

$\mathrm{POP}_{i t}$ : Natural logarithm of population, averaged over the years $t$ to $t+3$. Source: Roodman (2004)

RELIGION ${ }_{i}$ : Index of religious fractionalization. Source: Alesina et al. (2003)

SETTLERS $i$ : Share of population of European origin in colonial times. Source: Angeles and Neanidis (2009)

STATEHIST $_{i}$ : State Antiquity Index, which measures the extent to which a political entity above the tribal level existed in the state's present territory in the years 1 to 1950. Source: Putterman (2007)

TRADE $_{i t}$ : Total trade relative to GDP in constant price PPP-adjusted terms, averaged over the years $t$ to $t+3$. Source: Penn World Tables 6.3

TROPICS $i$ : Fraction of a country's area located in the tropics. Source: Gallup et al. (1999) 